\title{
Juletræet i Kokkedal. En sag om religion, nation og politik
}

\author{
Margit Warburg \\ professor, dr.phil., Institut for Tværkulturelle og Regionale Studier, Københavns Universitet
}

\begin{abstract}
I 2012 besluttede det muslimske flertal i bestyrelsen for en almennyttig boligforening at aflyse det fælles juletræ. Beslutningen vakte en heftig, landsdækkende debat i pressen, og politikere og andre meningsmagere var stærkt uenige om, hvorvidt juletræet var af national eller religiøs betydning i Danmark. Uenigheden kan forklares ved, at juletræet er et civilreligiøst symbol og derfor rummer referencer til både religion og nation.
\end{abstract}

I en kort periode op mod jul i 2012 blev den almennyttige boligforening Egedalsvænge i Kokkedal herostratisk berømt. Anledningen var, at det muslimske flertal i boligforeningens bestyrelse besluttede at aflyse en fast juletradition, nemlig at sætte et juletræ op på ejendommens fællesareal i december måned. Det viste sig hurtigt at blive en kontroversiel sag, som havde mere end lokalpolitisk interesse. I løbet af ganske få dage eksploderede debatten $i$ alle medier med utallige kommentarer om juletræer som dansk tradition, om integrationen af indvandrere og om forholdet mellem kristendom og islam i Danmark.

Konfliktens udvikling viste nogle interessante forskelle mellem den lokalpolitiske tilgang til konfliktløsning og de uomtvisteligt mere ansvarsfrie, symbolpolitiske markeringer i Folketinget og i de landsdækkende medier. Men konflikten afdækkede også nogle bemærkelsesværdige forskelle i de offentlige stemmers fortolkninger af konfliktens årsager og forløb - forskelle, som var centreret om juletræets nationale og/eller religiøse betydning i Danmark. I denne artikel vil jeg analysere disse forskelle ud fra blandt andet det religionssociologiske begreb civilreligion.
Jeg begynder med en kort introduktion af civilreligion og gennemgår derefter konfliktens forløb. Mit kildemateriale er først og fremmest de skrevne medier, som jeg for overskuelighedens skyld henviser til i noterne. Herefter argumenterer jeg for juletræets betydningsfulde position i dansk civilreligion, og jeg afslutter med at introducere en grafisk model, som jeg bruger til at analysere de forskellige udtalelser og fortolkninger af sagen i den offentlige debat for at kunne sætte dem ind i en civilreligiøs forståelsesramme.

\section{Civilreligion i korthed}

Den amerikanske sociolog Robert N. Bellah påpegede i et berømt essay, „Civil Religion in America“ (1967), at mange af de amerikanske præsidenters taler har været præget af en religiøs legitimering af den amerikanske nation og den amerikanske forfatning. Med et lån fra filosoffen Jean-Jacques Rousseaus (1712-1778) tanker om en samfundsreligion, en religion civile (Rousseau 1987) hævdede Bellah, at denne karakteristiske form for legitimering var udtryk for, at der faktisk eksisterede en samlende amerikansk civilreligion, som de fleste amerikanere kunne genkende som udtryk for en amerikansk national selvforståelse.

Bellahs artikel affødte en livlig diskussion og også betydelig kritik i 1970'erne og 1980'erne. Diskussionen drejede sig blandt andet om forskellige definitioner på amerikansk civilreligion, og om der egentlig var tale om ét, samlet fænomen, eller om civilreligion dækkede over forskellige, delvist overlappende fremtrædelsesformer, hvor den nationale selvforståelse og det nationale fællesskab var forbundet med det guddommelige (Coleman 1970; Gehrig 1981). Det er ikke på sin plads her at gen- 
nemgå denne diskussion, som er opsummeret flere steder, senest af Marcela Cristi og Lorne Dawson (2007) og på dansk af Margit Warburg (2013). Men trods kritikken har selve begrebet civilreligion vundet en blivende plads i religionssociologien.

Civilreligion er ikke et særligt amerikansk fænomen, men genfindes i mange andre lande. Alle danskere kender til - men bekender sig næppe til - myten om Dannebrog, som Gud lod falde ned fra himlen for at hjælpe danskerne i et slag i Estland den 15. juni 1219. Selv om det historiske belæg for den danske konges brug af det røde korsbanner ikke rækker længere tilbage end sidst i 1300-tallet (Adriansen 2003, 127-129), så fejres Valdemarsdag den 15 . juni stadig officielt bredt rundt om i landet, herunder med en særgudstjeneste i Holmens Kirke, hvor der holdes en tale til flagets pris af en højtstående politiker (Warburg 2008). Det er typisk civilreligion, nemlig dyrkelsen af en påstand om, at nationen eller folket nyder en særlig guddommelig beskyttelse. Eller formuleret lidt mere definitorisk, så er civilreligion en betegnelse i religionssociologien for en samlet videnskabelig forståelse af forskellige ritualer, myter, tekster, bygninger, mindesmærker og symboler, som har det til fælles, at de refererer til nationen og landet som noget, der har en særlig, transcendent bevågenhed (Hammond 1976; Warburg 2013).

Civilreligiøse markeringer i det offentlige behøver dog ikke altid at være landsdækkende. For eksempel afholder Fredericia by hvert år 6 . juli-festen til minde om sejren ved Fredericia, den 6. juli 1849 i den Første Slesvigske krig (Treårskrigen). Natten til 6. juli foretog den indesluttede danske hærstyrke i Fredericia fæstning et overraskende udfald og slog de belejrende slesvig-holstenske styrker på flugt efter blodige kampe. Festen er den store lokale begivenhed i Fredericia, og både sejren og de faldne mindes med en gudstjeneste, med tale af borgmesteren, og med parader, hvor Gud prises for støtten til hæren og den danske sag (Warburg 2006). Så selv om 6. juli-festen er en lokal begivenhed, gælder den guddommelige bevågenhed stadigvæk den danske nation, og ikke Fredericia by.

Civilreligion har således nation og religion som de to centrale dimensioner. Civilreligion er nemlig udtryk for en national selvforståelse sat ind i en religiøs referenceramme (Warburg 2013). Civilreligion er altså ikke en verdslig erstatning for religion; den har en religiøs natur forstået på den måde, at den refererer til det transcendente, som regel Gud. Men civilreligion er på den anden side heller ikke en religion, som har tilhængere i normal forstand, for der eksisterer for eksempel ingen gruppe af danskere, som af sig selv identificerer sig som tilhængere af dansk civilreligion. Civilreligion er således ikke en emic (intern) kategori, den er alene et etic (eksternt) begreb konstrueret af forskerne (se Pike 1967 om emic og etic).
Civilreligion i Danmark viser sig som empirisk fænomen i de forskellige situationer og steder, hvor borgerne enkeltvis eller samlet inddrager religion, når de dyrker nationen og deres tilhørsforhold til nationen. Faktisk er Danmark rig på civilreligion i form af fester, sange, ritualer og symboler, hvor det guddommelige sættes i forbindelse med den danske nation (Warburg et al. 2013).

\section{Optakten}

Sagen om juletræet begyndte med en afstemning på et bestyrelsesmøde den 31. oktober 2012 i Egedalsvænge. Blandt bestyrelsens ni medlemmer stemte en majoritet på fem - alle muslimer - uventet imod at opsætte og bekoste det sædvanlige juletræ på fællesområdet. ${ }^{1}$ Afdelingsbestyrelsens formand, Karin Leegaard Hansen, var blandt dem, der stemte for juletræet, og hun fortalte senere i et interview, at hun var chokeret over flertallets beslutning, og havde talt imod den, fordi hun var overbevist om, at de fleste beboere ønskede det traditionelle juletræ. ${ }^{2}$ Det hører også med i billedet, at tidligere i oktober 2012 havde samme bestyrelse arrangeret og bekostet en stor fælles eid-fest. Eid-festen er den muslimske fest, som markerer afslutningen af fastemåneden ramadan, og den kan fejres både i familiens skød og med store fællesarrangementer. Eid-festen i Egedalsvænge havde kostet ca. 60.000 kr.; til sammenligning var budgettet for juletræet ca. $7.000 \mathrm{kr}$. inklusive gløgg og æbleskiver til juletræsfesten. ${ }^{3}$

Onsdag den 7. november bragte Frederiksborg Amts Avis nyheden om den kontroversielle beslutning i en grundig reportage med kommentarer fra lokale beboere, en lokalpolitiker, som selv boede i Egedalsvænge, og to forskere. ${ }^{4}$ På det tidspunkt havde en af beboerne taget initiativ til en indsamling for at dække omkostningerne ved juletræet, så afgørelsen var åbenbart allerede kendt blandt beboerne, da Frederiksborg Amts Avis tog fat i sagen. ${ }^{5}$

Reportagen i Frederiksborg Amts Avis gav startskuddet til en landsdækkende mediedebat, som fortsatte november ud. Allerede ved udgangen af samme uge, dvs. søndag den 11. november havde Infomedia 165 referencer på sagen i danske dagblade og lokale ugeaviser. Dagen før kunne Ekstra Bladet meddele, at de havde haft en rekordstor aktivitet på deres hjemmeside med 5.127 blogkommentarer og 180 læserbreve med kommentarer til beslutningen om ikke at opsætte et juletræ i Egedalsvænge. ${ }^{6}$

De efterfølgende lokalpolitiske reaktioner kom den 8 . november. Venstre i Fredensborg var de første til at fordømme afdelingsbestyrelsens beslutning og opfordrede til, at man omgjorde den. Samtidig tilbød Venstre at sponsorere et juletræ til boligforeningen. ${ }^{7}$ Om eftermiddagen udsendte Fredensborgs socialdemokratiske borgmester, Thomas Lykke Pedersen, en pressemeddelelse, hvor han gav udtryk for, at bestyrelsen efter hans mening 
havde truffet en forkert beslutning, og han opfordrede dem til at genoverveje den. ${ }^{8}$

Men landspolitikerne nåede at overhale lokalpolitikerne indenom. Allerede om eftermiddagen den 7. november i Folketingets spørgetime bad Martin Henriksen fra Dansk Folkeparti kulturminister Uffe Elbæk om hans holdning til sagen. ${ }^{9}$ Ministeren svarede, at han som kulturminister ikke skulle blande sig i en lokalforenings beslutninger, uanset om man personligt var enig eller ej. ${ }^{10}$ Martin Henriksen ville dog ikke nøjes med denne afvisning, og efter en del ordveksling, hvor Henriksen understregede traditionernes betydning, endte kulturministeren med at udtale, ,at traditioner jo hele tiden er til debat og til forhandling ". ${ }^{11}$ Ud fra en sociologisk eller antropologisk synsvinkel kan der siges at være en vis dækning for ministerens udtalelse, hvis man ser den som en nøgtern observation af samfundslivet. Men den blev opfattet som en værdipolitisk udtalelse, og det fik Venstres kulturordfører Michael Aastrup Jensen til at kalde kulturministeren i samråd, hvor Jensen ville have en forklaring på Elbæks udtalelser, som han kaldte „beskæmmende“. ${ }^{12}$ I dagene efter kritiserede adskillige kommentatorer også Elbæk kraftigt for hans svar om, at traditioner var til forhandling. ${ }^{13}$ Kulturministeren fastholdt dog sit synspunkt i et indlæg i Berlingske den 17. november. ${ }^{14}$

Inden november måned var gået, nåede tre andre ministre også at involvere sig i diskussionen om det aflyste juletræ i Kokkedal, nemlig boligminister Carsten Hansen, kirke- og ligestillingsminister Manu Sareen og social- og integrationsminister Karen Hækkerup. ${ }^{15}$ Den lokalpolitiske affære var tydeligvis blevet en landspolitisk sag af en vis betydning. Det manglende juletræ rørte åbenbart ved noget centralt.

\section{Afdelingsbestyrelsens forklaringer}

Tilbage i Egedalsvænge sad de fem muslimske bestyrelsesmedlemmer og skulle forsvare deres beslutning i mediestormen. Den 8. november blev en af bestyrelsesmedlemmerne interviewet af Ekstra Bladet, og han afviste først vredt at forklare, hvad der var sket, idet han hævdede, at han havde tavshedspligt. ${ }^{16}$ Den efterfølgende dag gav de fem bestyrelsesmedlemmer imidlertid et gruppeinterview til Ekstra Bladet. ${ }^{17}$ Her gav de som begrundelse for, at boligforeningen ikke skulle have et fælles juletræ, at de som muslimer, der ikke selv holdt jul, ikke var forpligtet til at påtage sig arbejdet med at indkøbe og rejse træet. Samtidig hævdede de, at det var der heller ikke andre, der ville, men det blev kraftigt bestridt af formanden i et andet interview samme dag. ${ }^{18}$ De fem bestyrelsesmedlemmer afviste også at ændre holdning, selv om de fik træet betalt af andre - nu var beslutningen taget. ${ }^{19}$
Den efterfølgende dag blev to af de fem bestyrelsesmedlemmer igen interviewet af Ekstra Bladet. Her blev det ene medlem citeret for, at:

... nogen forsøgte at lokke ham i en fælde ved at få gruppen til at stemme nej til juletræet.

- Og nu ser det pludselig ud, som om vi er de onde muslimer, som vil dræbe julen. ${ }^{20}$

Det andet medlem beskyldte nogen - formodentlig formanden Karin Leegaard Hansen - for at have forfalsket mødereferatet. ${ }^{21}$ Ekstra Bladet fik imidlertid ikke lejlighed til at konfrontere formanden med denne påstand, og i det hele taget efterlader sagen et indtryk af forvirring og halve sandheder uden nogen faktuel forklaring på, hvorfor de fem bestyrelsesmedlemmer traf den kontroversielle beslutning.

Konflikten optrappedes nu i Egedalsvænge, hvor nogle af beboerne var begyndt at samle underskrifter ind med henblik på at vælte bestyrelsen ved en ekstraordinær generalforsamling. ${ }^{22} \mathrm{Da}$ to journalister fra TV2 ville dække underskriftindsamlingen, blev de mødt med vrede tilråb fra en stor gruppe unge med hættetrøjer og tildækkede ansigter. De unge smadrede TV-bilens ruder, døre og instrumentbræt, og journalisterne flygtede fra stedet. ${ }^{23}$ Det gik også ud over formanden for bestyrelsen, Karin Leegaard Hansen, som fik knust en rude i sin lejlighed. ${ }^{24}$

Disse voldelige episoder fik borgmesteren i Fredensborg, Thomas Lykke Pedersen, til den 13. november at reagere med et åbent brev til bestyrelsen. I brevet redegjorde han for de store investeringer, som kommunen havde lagt $\mathrm{i}$ at forbedre forholdene i Kokkedal, og understregede, at striden om juletræet havde skadet Kokkedal meget. ${ }^{25}$ Han opfordrede endnu en gang bestyrelsen til at genoverveje beslutningen, og han opfordrede også bestyrelsen til at tage skarpt afstand fra hærværket mod TV2-bilen. Samtidig skrev tre lokalpolitikere med muslimsk baggrund en tilsvarende opfordring til bestyrelsen om at arrangere en ny afstemning efter en demokratisk debat. De fremhævede også det sørgelige i, at „en offentlig debat bliver til et spørgsmål om religion, intolerance og eksklusion og i et hug tager alle de muslimske borgere i kommunen til indtægt for beslutningen om juletræet “. ${ }^{26}$ Venstres borgmesterkandidat Thomas Elgaard opfordrede i en pressemeddelelse direkte bestyrelsen til at ændre sin beslutning og koncentrerede sig i øvrigt om at fordømme hærværket på TV2-bilen som et angreb på ytringsfriheden. ${ }^{27}$

Det er sigende, at hverken borgmesteren eller Venstres borgmesterkandidat med et eneste ord omtalte den kendsgerning, at de fem bestyrelsesmedlemmer var mus- 
limer. For den socialdemokratiske borgmester var sagen åbenbart en social- og boligpolitisk udfordring, og venstrepolitikeren argumenterede med lov og orden og et ønske om gensidig respekt. Det var kun de tre muslimske lokalpolitikere, som indførte religion og kultur som bagvedliggende faktorer og nævnte, at for nogle var striden om juletræet et vigtigt religiøst spørgsmål, mens det for andre var et spørgsmål om at opretholde en hyggelig kulturel tradition. En forklaring på denne forskel kunne være, at de ikke-muslimske politikere tilhører majoriteten og formodentlig har indset, at de kan risikere at støde minoriteten, nemlig deres muslimske vælgere fra sig, hvis de forbinder bestyrelsens kontroversielle beslutning med religion. Men religion var den udslagsgivende årsag ifølge de fem bestyrelsesmedlemmers egen forklaring i interviewene til Ekstra Bladet. ${ }^{28}$ De ville som muslimer ikke påtage sig at arrangere et juletræ, når de ikke selv holdt jul. Jeg fortolker det sådan, at de muslimske lokalpolitikere godt kunne tale om religion, fordi de selv var muslimer og derfor ikke kunne mistænkes af bestyrelsen i Egedalsvænge for en skjult anti-muslimsk holdning.

\section{Afslutningen}

Den 14. november 2012 besluttede boligselskabet 3 B, hvorunder Egedalsvænge hører, at der skulle indkaldes til en ekstraordinær generalforsamling med nyvalg af bestyrelse. ${ }^{29}$ Beslutningen om at aflyse det traditionelle juletræ havde splittet beboerne, og konflikten i Egedalsvænge tilspidsedes yderligere, da gruppen Stop Islamiseringen Af Danmark varslede en demonstration den 1. december i selve Egedalsvænge, hvorefter Antifascistisk Aktion straks annoncerede en moddemonstration. ${ }^{30}$

Generalforsamlingen blev holdt den 28. november; der var mellem 300 og 400 deltagere, og politiet var mødt talstærkt op. Efter et langt møde lykkedes det at få valgt en ny formand og en ny bestyrelse. ${ }^{31}$ Bestyrelsen handlede hurtigt, for allerede den 30. november havde den indkøbt et juletræ og havde arrangeret, at det blev sat op på sin vante plads på taget af et pagodeformet læskur midt på fællesarealet mellem bygningerne. ${ }^{32}$

De anmeldte demonstrationer blev aflyst, og efter mere end tre ugers intens debat kunne medierne endelig slappe af og meddele, at julefreden var reddet. ${ }^{33}$

\section{Juletræet som civilreligiøst symbol}

Traditionen med et pyntet grantræ ved juletid blev indført fra Tyskland først i 1800-tallet, og fra midten af århundredet var det blevet almindeligt $\mathrm{i}$ borgerskabet at have et juletræ i hjemmet til jul. Det var en tid med nationalistisk vækkelse i Danmark, og skikken at pynte træet med flagguirlander stammer fra dengang (Adriansen 2003: 137). Det var i øvrigt især i grundtvigske kredse, at man pyn- tede juletræet med dannebrogsflag, mens missionsfolk gik imod denne sammenblanding af det nationale med det kristne (Havsteen-Mikkelsen 2014). Den populære juletræssang, „Højt fra træets grønne top“, blev skrevet i 1847 af Peter Faber som en lejlighedssang til en familiejul (Jensen 2014). Sangen omtaler hverken Gud eller Jesus og er i det hele taget en helt igennem sekulær julesang. Det er også en national julesang, og verset med Henrik, som „svinger fanen kækt“, og hvor digteren formaner de yngre børn: „Vid det er en ære, Dannebrog at bære“, er blevet tilføjet i 1848, året for Treårskrigens udbrud (Jensen 2014). Skikken med et juletræ bredte sig efterhånden til andre samfundsklasser, og omkring Første Verdenskrig var der juletræ i næsten alle hjem og også i det offentlige rum. ${ }^{34}$

Hvad angår juletræets religiøse betydning, så bemærkede kulturhistorikeren Troels-Lund for hundrede år siden, at juletræet sammen med julenisser og gåsesteg ,staar i lidet eller intet Forhold til Kristendommen " (Troels-Lund 1914-1915: 19). Juletræet var måske først og fremmest udtryk for en banal dansk nationalisme (Billig 2006).

Senere indoptog kirken juletræet i forbindelse med gudstjenesterne omkring jul, og i dag er der som regel et pyntet juletræ i kirkerne i december måned. Så juletræet er efterhånden blevet kristnet i Danmark, og denne nye religiøse referenceramme om et nationalt symbol gør juletræet til et civilreligiøst symbol. Det er også et centralt civilreligiøst symbol, for julen er årets store højtidelighed og familiefest for de fleste danskere. ${ }^{35}$ Men det er klart, at der er meget forskel på, hvor stor en religiøs betydning julen har for forskellige mennesker, og det afspejler sig i de mange forskellige avisindlæg og kommentarer til striden omkring juletræet i Kokkedal.

\section{Indlæg og kommentarer}

Ifølge min optælling i Infomedia har der alene i perioden fra 6. november til 31. december 2012 været mindst 654 omtaler af juletræssagen i danske dagblade og lokale ugeaviser. Mange af dem er selvfølgelig gengangere, hvor meddelelser fra Ritzaus bureau er flittigt genbrugt. Det faktuelle sagsforløb er afdækket gennem opsøgende journalistik, hvor især Frederiksborg Amts Avis, Ekstra Bladet og hoersholm.lokalavisen. $d k$ har været aktive. De mange presseindlæg gengiver desuden forskellige holdninger til sagen i form af interviews, læserbreve og kronikker. Disse mange indlæg udgør tilsammen et materiale, som dækker de vigtigste synspunkter på juletræssagen, som den har taget sig ud gennem pressedækningen. ${ }^{36}$

I den følgende analyse af materialet har jeg især interesseret mig for indlæg, hvor skribenten eller interviewpersonen så på konflikten som et nationalt og/eller et religiøst spørgsmål. Jeg vil i det følgende kort gennemgå nogle karakteristiske typer af sådanne kommentarer. 
Nogle kommentatorer, blandt dem et par danske lutherske teologer, argumenterede for, at striden om opsætningen af juletræet i Kokkedal var religiøs, dvs. det var en konflikt mellem islam og kristendommen. En af dem hævdede, at muslimer og de, som prædiker „religiøs neutralitet“, er ansporet af et „had til kristendommen“, og en anden kommentator advarede mod denne „kombinerede islamisering og kulturafvikling af kristendommen " ${ }^{37}$ Iben Thranholm, som er en kendt katolsk kommentator, konkluderede, at sagen først og fremmest viste svaghed fra de kristnes side, når det gjaldt forsvaret af egne traditioner, og hun fandt denne svaghed som en større trussel mod dansk kristen kultur end islam. ${ }^{38}$

Nogle af de muslimske lokale beboere, som var imod bestyrelsens beslutning om ikke at anskaffe et juletræ, antydede tilsvarende, at der lå religiøse motiver bagved. ${ }^{39}$ Det er jo umiddelbart også, hvad de fem bestyrelsesmedlemmer selv sagde i gruppeinterviewet, hvor de blandt andet begrundede beslutningen med, at de var muslimer. ${ }^{40}$ Ifølge flere anonyme udtalelser fra beboerne kunne beslutningen have været taget under påvirkning fra konservative muslimske kredse i lokalområdet, men generelt nægtede de interviewede at uddybe dette. ${ }^{41}$ Som den tidligere formand for bestyrelsen, Karin Leegaard Hansen, sagde: „Sådan noget spørger man jo ikke hinanden om“. ${ }^{42}$

Direkte adspurgt afviste bestyrelsen i gruppeinterviewet i Ekstra Bladet verserende rygter om, at Hizb utTahrir var involveret. ${ }^{43}$ I november 2013 bekræftede en medierepræsentant for Hizb ut-Tahrir imidlertid, at de havde rådgivet de muslimske bestyrelsesmedlemmer om deres håndtering af pressen i forbindelse med beslutningen om at aflyse det fælles juletræ i Egedalsvænge. ${ }^{44}$

En anden tilgang til striden om juletræet i Kokkedal var, at den primært drejede sig om dansk kultur over for „muslimsk kultur“. Denne fortolkning var først og fremmest repræsenteret af politikere fra Dansk Folkeparti, som fordømte bestyrelsens beslutning med ord som: „et uanstændigt angreb på dansk kultur“, „en konflikt mellem muslimsk og dansk kultur“, og et „frontalangreb på de danske værdier og traditioner". ${ }^{45}$ Den konservative Tom Behnke fulgte også denne linje, da han udtalte:

Jeg synes, det er stærkt foruroligende, at vores integrationsindsats åbenbart er så haltende, at man i det øjeblik, der er et muslimsk flertal, fjerner gode gamle danske traditioner og indfører muslimske i stedet for. ${ }^{46}$

Blandt de mange muslimer, som blev interviewet om sagen, mente de fleste interessant nok også, at juletræet først og fremmest var en dansk tradition og ikke så meget en kristen tradition. ${ }^{47}$ Et illustrativt eksempel blev bragt af Lolland-Falsters Folketidende den 7. december 2012, kort tid efter at striden i Kokkedal var endt med, at der som nævnt alligevel blev rejst det traditionelle juletræ i Egedalsvænge. Avisen havde en reportage fra en vellykket juletræsfest i et muslimsk domineret boligkompleks i $\mathrm{Ny-}$ købing Falster. Deltagerne var både etniske danskere og indvandrere af et dusin forskellige nationaliteter, og alle dansede rundt om juletræet, sang julesange og -salmer, og spiste æbleskiver. En af arrangørerne understregede, at festen blev holdt som en helt traditionel dansk juletræsfest, bortset fra, at gløggen var erstattet af varm kakao. ${ }^{48}$ To muslimske piger, som havde været med til at arrangere festen, sagde: „Det er jo bare hygge. Det handler ikke rigtigt om religion“. En af pigernes veninder tilføjede, at „Dem, der gør det deroppe i Kokkedal, overdriver det med religion. Det er dumt. ${ }^{\text {(49 }}$

\section{Striden om juletræet og det civilreligiøse rum}

Som omtalt i det foregående er juletræet et centralt civilreligiøst symbol i Danmark. For nærmere at kunne analysere de forskellige synspunkter på konflikten om juletræet i Kokkedal ud fra en sådan forståelse af juletræets symbolik er det illustrativt at benytte min nyligt foreslået grafiske model for „det civilreligiøse rum“ (Warburg 2013). Modellen, der er vist i figur 1, viser de to dimensioner af civilreligion, nemlig nation og religion, som to akser vinkelret på hinanden. Imellem de to akser kan man afgrænse det civilreligiøse rum, som er angivet med den åbne kurve. Her er både religion og nation til stede i gensidig henvisning til hinanden. Civilreligion skal nemlig rumme noget af begge dele, og samtidig skal civilreligion kunne adskilles fra religion på den ene side og nationalisme på den anden side (Hvithamar 2009).

En begivenhed, et ritual, et symbol eller andet, som vi antager at være udtryk for civilreligion, kan nu placeres i modellen, alt efter hvor stærkt de to dimensioner, religion og nation, kommer til udtryk. Det skal understreges, at det er en kvalitativ vurdering, der bygger på et skøn, og ikke et kvantitativt mål for mængden af henholdsvis religion og nation. En placering inden for det civilreligiøse rum, kræver, at begge dimensioner er udtrykt i betydelig grad. En placering uden for det civilreligiøse rum betyder, at det vi undersøger, tilhører enten kategorien religion eller kategorien nation. Det grå område i figuren repræsenterer i den forbindelse den logiske udelukkelse af et rum, der repræsenterer for lidt nationalisme og for lidt religion til at tillade en meningsfuld klassificering i henhold til modellen. 
Figur 1. Det civilreligiøse rum med indplacering af begivenheder efter den relative vægt af henholdsvis nationalisme og religion

Område, hvor hverken nation

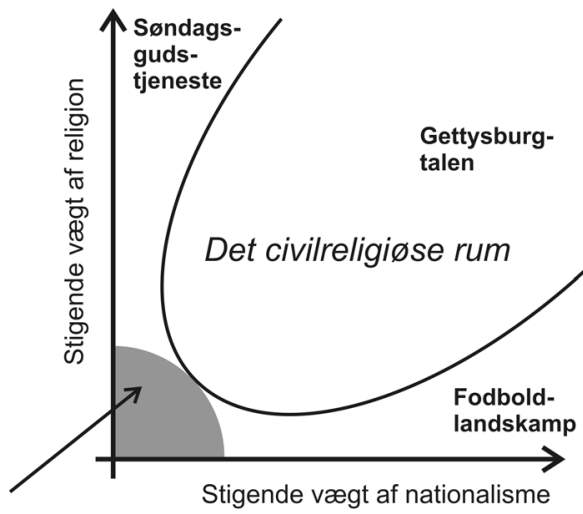

eller religion kommer til udtryk

Til illustration kan jeg tage et velkendt eksempel på civilreligion i USA. Det er Gettysburg-talen - den berømte tale, som præsident Abraham Lincoln gav i 1863 under den amerikanske borgerkrig ved indvielsen af soldaterkirkegården på slagmarken ved Gettysburg. Talens afslutningsord er uomtvisteligt et udtryk for civilreligion:

... that we here highly resolve that these dead shall not have died in vain-that this nation, under God, shall have a new birth of freedom-and that government of the people, by the people, for the people shall not perish from the earth. ${ }^{50}$

Ordene: „this nation under God" nævner de to centrale dimensioner i civilreligion, nemlig nation og religion, og de udtrykker også det særlige forhold mellem nationen og det transcendente, nemlig „under God“. Gettysburgtalen er derfor centralt placeret i det civilreligiøse rum.

Et eksempel på en begivenhed uden for det civilreligiøse område, men i øvrigt et grænsetilfælde, er en fodboldlandskamp. Der er nationalistiske følelser på højkant blandt tilskuerne, men spillere og tilskuere påberåber sig sjældent Gud eller andre transcendente magter for at få hjælp til at vinde. Derfor vil jeg placere fodboldlandskampen uden for det civilreligiøse rum og tæt ved nations-aksen.

Omvendt vil vi klart placere en almindelig gudstjeneste i den evangelisk-lutherske folkekirke i Danmark i kategorien religion. Der er ganske vist et mindre element af nationalisme forbundet med gudstjenesten, for Dannebrog vejer på flagstangen uden for kirken, og kirkebønnen efter prædikenen indeholder normalt en lille civilreligiøs forbøn i form af ordene „Hold din beskærmende hånd over vort folk og fædreland og al dets øvrighed ..." ${ }^{51}$ Men alligevel er det urimeligt at kalde en søndagsgudstjeneste for civilreligion, for i så fald udvides begrebet civilreligion ud over dets analytiske anvendelighed. I modellen er søndagsgudstjenesten derfor placeret tæt på religionsaksen og uden for det civilreligiøse rum.

Jeg vil nu vende tilbage til analysen af de forskellige synspunkter, som blev fremsat i pressen i forbindelse med aflysningen af det fælles juletræ i Egedalsvænge. Som anført i indledningen, er civilreligion alene et etic begreb konstrueret af forskerne. Man kan derfor ikke forvente, at nogen af debattørerne eksplicit så på striden om juletræet i Kokkedal som et spørgsmål om dansk civilreligion. Ved at placere de forskellige grupper af synspunkter i modellen for det civilreligiøse rum får vi et tydeligt indtryk af gruppernes vægtning af henholdsvis nationalisme og religion. Det er gjort i figur 2.

Figur 2. Det civilreligiøse rum med indplacering af kommentarer $i$ pressen i forbindelse med striden om juletræet i Kokkedal

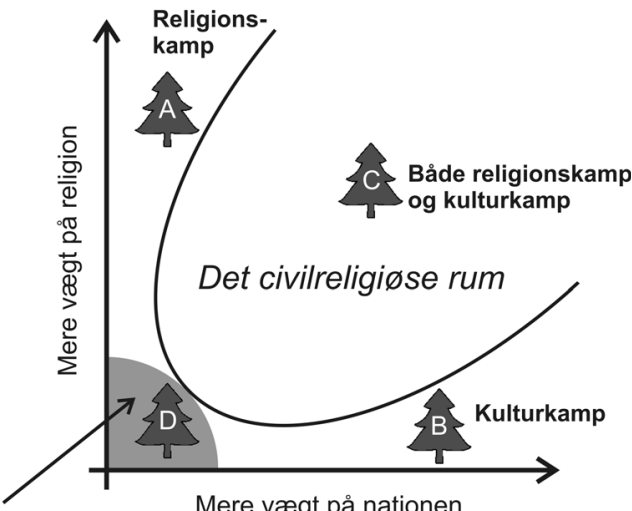

Område, hvor hverken nation eller religion kommer til udtryk

Den første gruppe, A, består af dem, der primært så sagen som et spørgsmål om religionskamp. Her har vi de kristne kommentatorer, som fremhævede en konfrontation mellem islam og kristendom. Gruppe A omfatter også de anonyme beboere, som antydede, at der var religiøse motiver bag bestyrelsens kontroversielle beslutning om at aflyse juletræstraditionen.

Den anden gruppe, B, så primært på sagen som et spørgsmål om konfrontation mellem dansk kultur og „muslimsk kultur“. De fremhævede de nationale og ikkereligiøse aspekter i et sådant kultursammenstød og så det ikke som en egentlig religionskamp. ${ }^{52}$

En tredje gruppe, C, så på forløbet af sagen som noget, der havde både nationale og religiøse aspekter. Hovedparten af repræsentanterne for denne gruppe var veluddannede kommentatorer. ${ }^{53}$ Position $\mathrm{C}$ passer med fortolk- 
ningen af juletræet som et dansk civilreligiøst symbol. Det er interessant, at de tre muslimske lokalpolitikere fra Fredensborg i deres appel til bestyrelsen i Egedalsvænge slog på, at der både kunne være en kulturel og en religiøs indgangsvinkel til en højtidsfest som julen. Det er tæt ved position C, selv om de ikke specifikt nævner dansk kultur.

Endelig var der synspunkterne repræsenteret ved D. Det var synspunkter fra en blandet gruppe af kommentatorer, som havde det til fælles, at de ikke så det som en konflikt af hverken religiøs eller national karakter. ${ }^{54}$ Kommentarerne fra mange danske muslimer ligger i denne gruppe - de støttede ikke bestyrelsens beslutning, men kritiserede den, fordi de frygtede, den ville forværre indbildte eller reelle modsætninger mellem de muslimske indvandrere og den danske befolkning. ${ }^{55}$ Flere af de muslimske kritiske røster tog også politisk stilling og understregede, at beslutningen var forkert ud fra et demokratisk synspunkt, fordi et demokrati også kræver en hensyntagen til mindretallets holdninger - i dette tilfælde de beboere i Egedalsvænge, som gerne ville have et juletræ. ${ }^{56}$

Man kan også henregne borgmester Thomas Lykke Pedersen og Venstres borgmesterkandidat Thomas Elgaard til gruppe D, da de jo som beskrevet ikke nævnte hverken de religiøse eller de nationale aspekter af sagen. Ingen af dem brugte i øvrigt lejligheden til ideologiske, partipolitiske markeringer, og de fulgte dermed den fremherskende tradition for konsensus i dansk kommunalpolitik (Pedersen et al. 2013: 46-49). Det er en ganske påfaldende forskel fra en række landspolitikeres konfrontative udtalelser i juletræssagen.

\section{Konklusion}

Juletræet er en del af dansk civilreligion, fordi det i en dansk sammenhæng både repræsenterer noget religiøst og ikke mindst noget vigtigt dansk. Det forklarer, hvorfor det gav anledning til en ophidset debat, da det muslimske flertal i bestyrelsen i Egedalsvænge besluttede at afskaffe juletræstraditionen mod mindretallets ønske. Samtidig var det uklart, hvad bestyrelsen ville meddele med beslutningen - var det „had til kristendommen“?57 Eller var det et „frontalangreb på de danske værdier"?58 Det er oplagt svært at nå til en fælles forståelse af sagens substans, når juletræet som civilreligiøst symbol forener det nationalt danske med det kristne.

Denne uklarhed omkring det religiøse versus det nationale er efter min opfattelse et iboende træk ved befolkningens forhold til det, vi kalder civilreligion. Synspunkter på civilreligiøse symboler, tekster, sange og ritualer osv. vil ofte kunne give sig forskellige udslag, hvor nogle fremhæver det nationale og andre det religiøse, mens atter andre vil sige, at det handler om begge dele. Sådan var det også i striden om juletræet, hvor nogle kommentatorer understregede det religiøse og så på konflikten som en modsætning mellem muslimer og kristne. Andre lagde vægten på det nationale og så på sagen som en national kulturkamp og et spørgsmål om integration. Og mellem disse yderpunkter var der også enkelte, der kunne se begge aspekter. Hele den offentlige polemik kan således efter min opfattelse med fordel analyseres ud fra civilreligionsbegrebet, fordi det forklarer, hvorfor der var så bred uenighed om fortolkningerne af bestyrelsens beslutning om at aflyse juletræet i Kokkedal.

\section{Referencer}

Adriansen, Inge 2003, Nationale symboler i det danske rige 1830-2000, vol. 1, Museum Tusculanum, København.

Andersen, Peter B. og Peter Lüchau 2011, 'Individualisering og aftraditionalisering af danskernes religiøse værdier', i Peter Gundelach (red.), Små og store forandringer. Danskernes vardier siden 1981, Hans Reitzel, København, pp. 76-96.

Bellah, Robert N. 1967, 'Civil Religion in America', Dadalus, vol. 96, pp. 1-21.

Billig, Michael 2006, Banal Nationalism, Sage, London.

Coleman, John A. 1970: 'Civil Religion', Sociological Analysis, vol. 31, pp. 67-77.

Cristi, Marcela og Lorne L. Dawson 2007: „Civil Religion in America and in Global Context“, i James A. Beckford og N.J. Demerath III (red.), The Sage Handbook of the Sociology of Religion, Sage, London, pp. 267-292.

Dansk Historisk Fællesråd 2014, 'Juletræets historie', http://www.historie-online.dk/special/jul/trae.htm, set 24. september 2014 .

Elbæk, Uffe 2012, 'Talepapir fra åbent samråd 28. nov. 2012', Kulturministeriet, Kulturudvalget 2012-13, KUU Alm. del Bilag 41.

Gehrig, Gail 1981: 'The American Civil Religion Debate: A Source for Theory Construction', Journal for the Scientific Study of Religion, vol. 20, pp. 51-63.

Hammond, Phillip E. 1976: 'The Sociology of American Civil Religion: A Bibliographical Essay', Sociological Analysis, vol. 37, pp. 169-182.

Havsteen-Mikkelsen, Mette Eriksen 2014, 'Kend din kirkelige retning på juletræet', http://www.grundtvig.dk/hvem-er-grundtvig/ temaer-i-grundtvigs-forfatterskab/grundtvig-i-hoejtiderne/grundtvig-i-julen/kend-din-kirkelige-retning-paa-juletraeet.html, set 24 . september 2014.

Hvithamar, Annika 2009, 'Nationalism and civil religion. What is the difference?', i Annika Hvithamar, Brian Jacobsen og Margit Warburg (red.), Holy Nations and Global Identities. Civil Religion, Nationalism and Globalisation, E.J. Brill, Leiden, pp. 99-118.

Jensen, Charlotte S.H. 2014, 'En lejlighedsjulesang...', https://www. sa.dk/Elearning_og_webudstillinger/temaer_til_inspiration/jul/ hoejt/historien.htm, set 24. september 2014.

Pedersen, Lene Holm, Kurt Houlberg, Sune Welling Hansen, Asmus Leth Olsen og Mats Joe Bordacconi 2013, Lokalpolitikeres rolle og råderum, KORA, Det National Institut for Kommuners og Regioners Analyse og Forskning, København.

Pike, Kenneth Lee 1967, Language in Relation to a Unified Theory of Structure of Human Behaviour, 2. edn.: Mouton, Hague.

Ringby, Christina 2012 'Lidt historie om Rådhuspladsens juletræ', https://bibliotek.kk.dk/biblioteker/raadhusbiblioteket/blog/lidthistorie-raadhuspladsens-juletrae, set 24. september 2014.

Rousseau, Jean-Jacques 1987, Samfundspagten, Rhodos, København. 
Troels-Lund, Troels Frederik (1914-1915), Dagligt Liv i Norden i det sekstende Aarhundrede, 4. edn., vol. 7, Aarlige Feste, Gyldendalske Boghandel, København.

Warburg, Margit 2006, 'Fra sørgemarch til sejrsmarch: Slaget ved Fredericia og dansk civilreligion i en globaliseringstid', Chaos. Dansknorsk tidsskrift for religionshistoriske studier, vol. 45, pp. 29-147.

Warburg, Margit 2008, 'Dannebrog: Waving in and out of Danish Civil Religion', Nordic Journal of Religion and Society, vol. 21, pp. 165183.

Warburg, Margit 2013, 'Gud bevare Danmark. Dansk civilreligion i det store og det små', i Margit Warburg, Signe Engelbreth Larsen og Laura Maria Schütze (red.), Civilreligion i Danmark. Ritualer, myter og steder, Forlaget Univers, Højbjerg.

Warburg, Margit, Signe Engelbreth Larsen og Laura Maria Schütze (red.) 2013, Civilreligion i Danmark. Ritualer, myter og steder, Forlaget Univers, Højbjerg.

\section{Noter}

1. Frederiksborg Amts Avis 7. nov. 2012, 8-9.

2. Ekstra Bladet 8. nov. 2012, 8; BT 8. nov. 2012, 10.

3. Frederiksborg Amts Avis 7. nov. 2012, 8-9.

4. Frederiksborg Amts Avis 7. nov. 2012, 8-9.

5. Frederiksborg Amts Avis 7. nov. 2012, 8.

6. Ekstra Bladet 10. nov. 2012, 8.

7. http://hoersholm.lokalavisen.dk 8. nov. 2012.

8. http://hoersholm.lokalavisen.dk 8. nov. 2012.

9. BT 8. nov. 2012, 10; Folketingstidende F 7. nov. 2012, 9.

10. BT 8. nov. 2012, 10; Folketingstidende F 7. nov. 2012, 9.

11. BT 8. nov. 2012, 10; Folketingstidende F 7. nov. 2012, 9.

12. BT 8. nov. 2012, 10. Det åbne samråd blev afholdt den 28. nov. 2012 (Elbæk 2012).

13. Katrine Winkel Holm i Jyllands-Posten 10. nov. 2012, 22; Sørine Godtfredsen i Berlingske 17. nov. 2012, 30; Sørine Godtfredsen i Kristeligt Dagblad 1. dec. 2012, 17; sognepræst Kristian Hein i Dagbladet 8. dec. 2012, 4.

14. Uffe Elbæk i Berlingske 17. nov. 2012, 30.

15. BT 9. nov. 2012, 25; Kristeligt Dagblad 29. nov. 2012, 1.

16. Ekstra Bladet 8. nov. 2012, 9.

17. Ekstra Bladet 9. nov. 2012, 12.

18. Ekstra Bladet 9. nov. 2012, 12.

19. Ekstra Bladet 9. nov. 2012, 12.

20. Ekstra Bladet 10. nov. 2012, 8.

21. Ekstra Bladet 10. nov. 2012, 8.

22. Ekstra Bladet 14. nov. 2012, 26.

23. Ekstra Bladet 12. nov. 2012, 11.

24. Jyllands-Posten 14. nov. 2012, 6

25. http://hoersholm.lokalavisen.dk 13. nov. 2012.

26. http://hoersholm.lokalavisen.dk 13. nov. 2012.

27. http://hoersholm.lokalavisen.dk 13. nov. 2012.

28. Ekstra Bladet 9. nov. 2012, 12; Ekstra Bladet 10. nov. 2012, 8

29. http://hoersholm.lokalavisen.dk 15. nov. 2012.

30. BT 16. nov. 2012, 12; http://modkraft.dk/artikel/antifascister-vilskabe-tryghed-i-kokkedal; http://projektantifa.dk/nyheder/article/ stop-racisterne-fra-kobenhavn-til, set 22. juli 2014.

31. BT 29. nov. 2012, 10; Jyllands-Posten 30. nov. 2012, 3.

32. Kristeligt Dagblad 1. dec. 2012, 2.
33. Ekstra Bladet 1. dec. 2012, 17.

34. Traditionen med byens store juletræ på Rådhuspladsen i København blev indført i 1914 på initiativ af Politikens daværende redaktør, Henrik Cavling (Ringby 2012).

35. Cirka en tredjedel af danskerne går i kirke ved højtiderne, hvilket først og fremmest er juleaftensdag, og antallet af kirkegængere den dag er steget betragteligt gennem de seneste tyve år (Andersen og Lüchau 2011).

36. Materialet er primært indhentet fra de landsdækkende aviser samt den lokale presse, især Frederiksborg Amts Avis og websiden sn.dkSjallands nyheder, som er fælles for en række sjællandske aviser uden for København.

37. Iben Tranholm i Kristeligt Dagblad 7. dec. 2012, 9; Katrine Winkel Holm i Jyllands-Posten, 10. nov. 2012, 22.

38. Iben Tranholm i Berlingske 25. nov., 2012, Debat 1.

39. Frederiksborg Amts Avis 7. nov. 2012, 8-9; Ekstra Bladet 8. nov. 2012, 10; BT 9. nov. 2012, 24.

40. Ekstra Bladet 9. nov. 2012, 12.

41. BT 9. nov. 2012, 24.

42. BT 9. nov. 2012, 24.

43. Ekstra Bladet 9. nov. 2012, 12.

44. Berlingske 6. nov. 2013, 6.

45. Martin Henriksen i Kristeligt Dagblad 8. nov. 2012, 3; Martin Henriksen i BT 8. nov. 2012, 10; Michael Nedersøe i Fredericia Dagblad, Folkebladet, 14. nov. 2012, 4.

46. Tom Behnke i Dagbladet, 10. nov. 2012, 4

47. Frederiksborg Amts Avis 7. nov. 2012, 9; Ekstra Bladet 8. nov. 2012, 10.

48. Lolland-Falsters Folketidende, 7. dec. 2012, 8.

49. Lolland-Falsters Folketidende, 7. dec. 2012, 8.

50. http://www.abrahamlincolnonline.org/lincoln/speeches/gettysburg.htm, set 22. juli 2014.

51. Højmesseordningen, autoriseret ved kgl. resolution af 12. juni 1992. http://www.folkekirken.dk/fileadmin/files/Pdf/H\%C3\%B8jmesse ordning.pdf, set 22. juli 2014.

52. Denne stillingtagen var meget på linje med sociologen Mehmet Ümit Necefs kommentar i Lolland-Falsters Folketidende, 10. nov. 2012, nogle få dage efter at striden om juletræet blev en mediebegivenhed.

53. Kathrine Lilleør i Berlingske 10. nov. 2012, 28; Mogens S. Mogensen i religion.dk, 12. nov. 2012; Marie Vejrup Nielsen i Politiken 2. dec. 2012, PS 5.

54. Historikeren og islamforskeren Jørgen Bæk Simonsen gav allerede samme dag, som striden blev offentligt kendt, udtryk for denne vurdering i Frederiksborg Amts Avis 7. nov. 2012, 9.

55. Naser Khader i Ekstra Bladet 8. nov. 2012, 10; Rushy Rashid i Ekstra Bladet 8. nov. 2012, 10; Walid Sharif i Ekstra Bladet 10. nov. 2012, 26; Nogle af de øvrige kommentarer fra muslimske danskere var i øvrigt utvetydigt negative og ret direkte („langt ude“, „hul i hovedet“ o.l.), se for eksempel Ekstra Bladet 8. nov. 2012, 9-10.

56. Muhammad Aslam i Ekstra Bladet 8. nov. 2012, 9; Fatma Øktem i Ekstra Bladet 8. nov. 2012, 10; Ømer Ciftci i Frederiksborg Amts Avis 9. nov. 2012, 9; Mehmet Zeki Köse i Kristeligt Dagblad 13. nov. 2012, 12; Yildiz Akdogan i Berlingske 16. nov. 2012.

57. Iben Tranholm i Kristeligt Dagblad 7. dec. 2012, 9.

58. Michael Nedersøe i Fredericia Dagblad, Folkebladet, 14. nov. 2012, 4. 